\title{
AGROBACTERIUM-MEDIATED GENE TRANSFORMATION OF POLLEN SPECIFIC GENE STK1 IN MAIZE (ZEA MAYS)
}

\author{
JAVEED, A. ${ }^{\#}-$ WU, S. ${ }^{3 \#}-$ HUANG, S. ${ }^{1}-$ AHMED, M. ${ }^{2}-$ SIKANDAR, A. ${ }^{2}-$ IQBAL, M. F. ${ }^{1}-$ \\ Dogar, U. F. ${ }^{4}-$ Zhang, C. ${ }^{1}-$ Chen, M. ${ }^{1}-$ LiU, C. ${ }^{1}-$ Hussain, K. ${ }^{4}-$ Feng, L. ${ }^{1 *}$ \\ ${ }^{1}$ College of Bioscience and Biotechnology, Shenyang Agricultural University, Shenyang, \\ Liaoning, China
}

${ }^{2}$ College of Plant protection, Shenyang Agricultural University, Shenyang, Liaoning, China

${ }^{3}$ College of Science Institute, Shenyang Agricultural University Shenyang, Liaoning, China

${ }^{4}$ Department of Botany, University of Gujrat, Hafiz Hayat Campus, Gujrat, Pakistan

${ }^{\#}$ These authors have equal contribution to this paper.

*Corresponding author

e-mail: fenglinsn@126.com; phone: +86-248-848-7086; fax: +86-248-848-7416

(Received 22 ${ }^{\text {nd }}$ Apr 2019; accepted $4^{\text {th }}$ Jul 2019)

\begin{abstract}
Maize is a major food, feed and fodder crop, grown extensively all over the world. Genetic engineering has a unique role in crop improvement. Serine-Threonine-Kinase1 (ZmSTK1) is a gene-based enzyme, which due to its biochemical action in maize pollen grains, lowers the survival capability and affects pollination. Out of different methods of genes transfer into the genome of the target cell, Agrobacterium-mediated gene transformation is an easy and convenient method in which required gene is insert into the Agrobacterium, which after multiplication carry foreign genes into the host cell's genome. In this research, a simple and easy Agrobacterium tumefaciens-mediated method used to establish the genetic transformation system of zmstkl into maize germinating embryo as receptor system. Transgenic plants obtained successfully through this method and the complicated culture process not needed. The expression of zmstkl in the tissue was determined by observing the histochemical localization of zmstkl in order to elucidate the expression of zmstkl in mature tassel or pollen.
\end{abstract}

Keywords: agrobacterium tumefaciens, gene editing, gene mutation, pollen viability, transgenetic maize

\section{Introduction}

Maize is a major crop found all over the world and used extensively for food, feed and fodder. Because of its consumption at large scale, some high yielding varieties have to be selected to meet the requirement. Naturally, dominant and vigorous varieties also play an important role in production of healthy and disease free food but for high production of maize, some controlled experiments on cellular and molecular level are required. Public and government affiliated institutions of agriculture research are investigating reasons related to adjustment of maize plant for biotic and environmental stresses. Transfer of genes of cold regions maize varieties to increase production and to improve quality, breeders focus on the improvement of new varieties by using these techniques. One of the major hurdles in functional use of this technique to temperate varieties of maize is the selection of germplasm responsible for its renaissance in tissue culture and inoculation by Agrobacterium (Souza et al., 2017). There are many ways to enhance the ability of an organism to produce the required yield of product such as natural hybridization, cellular metabolism enhancement, quantitative trait loci, molecular and genetic recombination and gene transformation into the cell. For different 
purposes, different methods and ways are used. One of the best and advanced research in genetic and molecular experiments is to transfer a specific target gene into the vegetative cells of plants. For this purpose, some experiments held in Shenyang Agricultural University Shenyang, Liaoning, China.

Agrobacterium-mediated transformation is a fast and more accurate method for gene transfer with high frequency and time saving approaches (Que et al., 2014). This method is more extensively adapted now days by both civil and private institutions, however, capability of transformation varies highly from lab to lab for the same plant genotype. Here, advanced Agrobacterium-mediated transformation technique in maize by using a simple form of binary vectors exemplified. This method uses undeveloped embryos as fundamental explants and the bar gene as a selectable marker together with bialaphos as a selective agent in maize (Shrawat and Good, 2011), rice (Hei and Komari, 2008) and in switchgrass (Xi et al., 2009). Development based on genetic transfer varies, in which gene can be inserted into plants more effectively which depend on the species or variety, or the genetic marker being used (Binka et al., 2012). In recent times, a CRISPR/Cas9 toolkit used for multiplex genomic editing in different host plants based on the pGreen and in pCambia backbone (Xing et al., 2014). Genetic changes in plants which effect pollen development can be easily observed by the unusual isolation of markers linked to it (Vasal et al., 2006) and in plants where the genetic changes are due to transposons that present a phenotype are by the abnormal isolation of responsible transposon itself (Lalanne et al., 2004; Boavida et al., 2009).

Serine threonine kinase1 (STK1) and serine threonine kinase2 (STK2) are closely related to paralogous genes of maize predicted to encode serine/threonine protein kinases. Those pollens, which have mutations of ZmSTK1 or ZmSTK2, can compete poorly with wild pollens, indicating to an abnormality in germination or growth of pollen tube. Both genes show their expression only in pollens but not in most of other parts of plants. In medium of germination, ZmSTK1 and ZmSTK2 fluorescent fusion proteins are located in the cell membrane of the somatic cell of plant. RNA-sequencing experiments indicated 534 genes, which expressed differentially in zmstkl mutant pollens as compared to wild type. Gene ontology molecular functional analysis revealed many differently expressed genes with supposed ribosome initiation and elongation functions, signifying that zmstkl may show effect on function of ribosomes. Of these two mutant forms, zmstkl may show a more imperative role in pollen development as compared to zmstk2, as mutations of zmstk2 have a smaller transmission effect in pollen development. However, zmstk 2 acts as a booster of zmstkl expression because the combination of double mutation shows that pollens are too weak to survive until fertilization as compared to wild and single mutants. Therefore, it is analyzed that the ZmSTK paralogs play an important role in pollen development (Huang et al., 2017).

New requirements need to develop some techniques for low copy transfer of genes into the target cell by A. tumefaciens (Sivamani et al., 2015). In these experiments, ZmSTK1 gene transferred into the cells of maize embryo during its initial growth time. For transformation of gene there are different ways used in the bio-scientific field, out of these methods Agrobacterium-mediated method of transformation was found as an easy and best way to transform the target gene into the maize embryo cells (Yadava et al., 2017). In this experiment, Agrobacterium tumefaciens used as a vector for multiplication to carry the gene ZmSTK1 into the target embryo cells and insert the gene into the genome of maize cells. 


\section{Materials and methods}

\section{Plant material}

Wild-type $\mathrm{McC}$ and mutant zmstkl provided by Dr. Dooner, Rutgers University, USA. The pMD18-T-pSTK1 recombinant plasmid and the $p C A M B I A 1301$ plasmid provided by the laboratory from the College of Bioscience and Biotechnology in Shenyang Agricultural University, China.

\section{Instruments and equipment}

Test thermostat incubator, PCR machine, refrigerated centrifuge, electrophoresis tank, gel electrophoresis, autoclave, water bath, gel imager, horizontal electrophoresis tank, DC power supply, shaker, $50 \mathrm{ml}$ centrifuge tube, tweezers, scalpel, and $2.0 \mathrm{ml}$ centrifuge tubes.

\section{Major reagents}

To make $1 \%$ Rifampicin, $0.1 \mathrm{~g}$ rifampicin dissolved in $10 \mathrm{ml}$ methanol, sterilized after filtration and stored at $-20^{\circ} \mathrm{C}$. To make 5\% kanamycin, $1.0 \mathrm{~g}$ kanamycin dissolved in $20 \mathrm{ml}$ distilled water, filtered, sterilized and preserved at $-20^{\circ} \mathrm{C}$. To make $50 \mathrm{~g} / \mathrm{l}$ ampicillin, $2 \mathrm{~g}$ ampicillin dissolved in $40 \mathrm{ml}$ distilled water, sterilized after filtration and stored at $-20^{\circ} \mathrm{C}$. For Acetosyringone solution, dimethyl sulfoxide dissolved in acetosyringone, $200 \mathrm{mmol} / \mathrm{l}$ solution was prepared, diluted with distilled water to make $100 \mathrm{mmol} / \mathrm{l}$, filtered and stored at $-20^{\circ} \mathrm{C}$. In addition, for $5 \%$ sodium hypochlorite solution, $50 \mathrm{ml}$ of pure sodium hypochlorite dissolved in sufficient amount of distilled water, raised the volume to $1 \mathrm{~L}$ and stored at room temperature. $70 \%$ ethanol was prepared by adding $70 \mathrm{ml}$ of pure ethanol, with the sufficient amount of distilled water and raised the volume $0.1 \mathrm{~L}$. To make YEB medium, $10 \mathrm{~g}$ tryptone, yeast $10 \mathrm{~g}$ extract and $0.5 \mathrm{~g} \mathrm{MgSO}_{4} .7 \mathrm{H}_{2} \mathrm{O}$ mixed with distilled water to raise the volume $1000 \mathrm{ml}$ and stored at $\mathrm{pH}$ 7.2. LB medium prepared by dissolving $10 \mathrm{~g}$ tryptone, $5 \mathrm{~g}$ yeast extract, $10 \mathrm{~g} \mathrm{NaCl}$ in distilled water, raised the volume to $1 \mathrm{~L}$, and stored at $\mathrm{pH}$ 7.0. For sodium phosphate buffer (100 mmol/l, pH 7.0), Solution A $\left(6.55 \mathrm{~g} \mathrm{NaH}_{2} \mathrm{PO}_{4} .2 \mathrm{H}_{2} \mathrm{O}\right.$ dissolved in $50 \mathrm{ml}$ of distilled water) and Solution $\mathrm{B}\left(1.83 \mathrm{~g} \mathrm{Na} 2 \mathrm{HPO}_{4} .12 \mathrm{H}_{2} \mathrm{O}\right.$ dissolved in $50 \mathrm{ml}$ of distilled water) mixed and volume raised to $200 \mathrm{ml}$ at $\mathrm{pH} 7.0$. X-Gluc prepared using (5-bromo-4chloro-3 indolylglucuronide) and mother liquor $(0.5 \mathrm{mg} / \mathrm{ml}) .0 .025 \mathrm{~g}$ of XGluc dissolved in $1 \mathrm{ml}$ of N-N-dimethyl amide (DMF) and stored at $-20{ }^{\circ} \mathrm{C}$. For X-Gluc base solution $(10 \mathrm{mmol} / \mathrm{l}), 0.1 \mathrm{~g}$ of $\mathrm{K}_{3} \mathrm{Fe}(\mathrm{CN})_{6}$ potassium ferricyanide $(1 \mathrm{mmol} / \mathrm{l})$ and $0.13 \mathrm{~g}$ of $\mathrm{K}_{4} \mathrm{Fe}(\mathrm{CN})_{6}$ were mixed in $200 \mathrm{ml}$ of sodium phosphate buffer, followed by the addition of $300 \mathrm{ul} 0.1 \%$ Triton X-100, $1.12 \mathrm{~g} \mathrm{Na} 2$ EDTA Potassium ferricyanide $(1 \mathrm{mmol} / \mathrm{l})$ and completely dissolved to make $250 \mathrm{ml}$.

\section{Construction of maize ZmSTK1 expression vector}

First competent cells of $E$. coliwere prepared by making LB medium, which used to flatten to activate Escherichia coli DH5a single colonies, stored overnight at $37{ }^{\circ} \mathrm{C}$. Then pre-activated single colony was selected, inoculated in $5 \mathrm{ml}$ LB liquid medium and culture was shacked for $12 \mathrm{~h}$ at $37^{\circ} \mathrm{C}$. After that $500 \mu \mathrm{l}$ bacteria inoculated to absorb in $50 \mathrm{ml} \mathrm{LB}$ liquid medium, shacked it at $37^{\circ} \mathrm{C}$ and bacterial suspension placed in the already cooled $1.5 \mathrm{ml}$ centrifuge tube and ice bathed for $15 \mathrm{~min}$. The cooled suspension centrifuged for $1 \mathrm{~min}$ at $4{ }^{\circ} \mathrm{C}$ at $8000 \mathrm{rpm}$. Supernatant discarded after 
removing the net residue of the culture medium and preserved in ice bath. Then suspended bacteria in a pre-cooled $\mathrm{CaCl}_{2}$ solution $(0.1 \mathrm{~mol} / \mathrm{l})$ at $4{ }^{\circ} \mathrm{C}$ and centrifuged for $1 \mathrm{~min}$ at $8000 \mathrm{rpm}$. Then $0.1 \mathrm{~mol} / \mathrm{l}$ suspension of bacteria centrifuged for $1 \mathrm{~min}$ at $8000 \mathrm{rpm}$ at $4{ }^{\circ} \mathrm{C}$ and supernatant removed by using $0.1 \mathrm{~mol} / 1 \mathrm{CaCl}_{2}$ solution. Supernatant discarded, net residual culture medium removed and $2 \mathrm{ml}$ pre-cooled $\mathrm{CaCl}_{2}$ solution $(0.1 \mathrm{~mol} / \mathrm{l})$ added for bacterial suspension. After that, $80 \%$ of the volume of glycerol added, mixed, and stored at $-80{ }^{\circ} \mathrm{C}$ in refrigerator for further use.

\section{Double digestion reaction}

The recombinant plasmids $p M D 18-T-p S T K 1$ and $p C A M B I A 1301$ plasmids digested with restriction endonuclease HindIII and NcoI. Table 1 shows the reaction system.

Table 1. Composition of system used for digestion

\begin{tabular}{c|c}
\hline System composition & Consumption \\
\hline pMD18-T-pSTK1 & $15 \mathrm{uL}$ \\
Hind III & $1 \mathrm{uL}$ \\
NcoI & $1 \mathrm{uL}$ \\
$10 *$ buffer (Enzyme digestion buffer) & $2 \mathrm{uL}$ \\
Double distilled $\mathrm{H}_{2} \mathrm{O}$ & $1 \mathrm{uL}$ \\
Total & $20 \mathrm{uL}$ \\
\hline
\end{tabular}

\section{Recycled digested product}

The enzyme digested with the kit and the digested product of pMD18-T-pSTK1 digested about 1000 bp and named HindIII-pSTK1-NcoI and pCAMBIA1301. The large fragment digested product named HindIII-pCAMBIA1301-NcoI.

\section{Binding with the expression vector}

HindIII-pSTK1-NcoI ligated with the vector HindIII-pCAMBIA1301-NcoI, and the binding system incubated at $14{ }^{\circ} \mathrm{C}$ for $14 \mathrm{~h}$ under the conditions of Table 2.

Table 2. Components of enzymatic systems

\begin{tabular}{c|c}
\hline System composition & Consumption \\
\hline T4 DNA Ligase & $2.0 \mathrm{uL}$ \\
T4 Ligase buffer solution & $2.0 \mathrm{uL}$ \\
Hind III- pCAMBIA1301-NcoI & $4.0 \mathrm{uL}$ \\
Hind III-pSTKI-NCoI & $12 \mathrm{uL}$ \\
Total & $20 \mathrm{uL}$ \\
\hline
\end{tabular}

\section{Conversion}

Thawed E. coli competent cells to complete melting drew $100 \mu$ into a new sterile centrifuge tube and immediately placed in ice. Then 5 - $\mu 1$ ligase enzyme added, mixed and placed in ice for $30 \mathrm{~min}$ followed by putting it in a hot water bath at $42{ }^{\circ} \mathrm{C}$ for $90 \mathrm{~s}$ and quickly placed in ice for $5 \mathrm{~min}$. Then 1-1 LB liquid medium added, mixed and shacked at $37^{\circ} \mathrm{C}$ for $1.5 \mathrm{~h}$ and centrifuged for $1 \mathrm{~min}$ at $8000 \mathrm{rpm}$, discarded the centrifugal supernatant and added $100 \mu \mathrm{l}$ LB liquid medium. The bacterial liquid 
coated on LB solid medium containing $50 \mathrm{~g} / \mathrm{l}$ of ampicillin and the surface placed up to the bacterial solution, completely absorbed by the culture medium and cultured at $37^{\circ} \mathrm{C}$ for 16 to $24 \mathrm{~h}$. Then a single colony picked and used PCR kit to mention the plasmid. After a double enzyme digestion, electrophoresis detection of recombinant plasmid used and digestion products tested in the positive plasmid named $p C A M B I A 1301-p S T K 1-G U S$ saved in refrigerator at $-80{ }^{\circ} \mathrm{C}$.

\section{Preparation of agrobacterium competent cells}

Agrobacterium tumefaciens EHA105 cultured on YEB solid medium containing $1 \%$ rifampicin and cultured at $28^{\circ} \mathrm{C}$ for $48 \mathrm{~h}$. Activated single colony selected, inoculated with $1 \mathrm{ml}$ liquid medium containing $1 \%$ rifampicin YEB and shacked at $28{ }^{\circ} \mathrm{C}$ overnight. $250 \mu \mathrm{l}$ of the bacterial solution was taken and incubated in $25 \mathrm{ml}$ of YEB liquid medium containing $1 \%$ rifampicin and shook at $28{ }^{\circ} \mathrm{C}$ until OD600 $=0.5$. Next, took the bacterial suspension, ice bathed for $15 \mathrm{~min}$ and centrifuged in a high speed centrifugal machine for $10 \mathrm{~min}$ at $5000 \mathrm{rpm}$ and supernatant was discarded. $5 \mathrm{ml} 0.15 \mathrm{~mol} / \mathrm{l} \mathrm{NaCl}$ suspension of bacteria was prepared, ice bathed for $15 \mathrm{~min}$ and centrifuged at $5000 \mathrm{rpm}$ for $10 \mathrm{~min}$. Then $2 \mathrm{ml} 0.1 \mathrm{~mol} / \mathrm{l} \mathrm{pre-cooled} \mathrm{CaCl}_{2}$ solution was prepared with cell suspension, $80 \%$ glycerol added and refrigerated at $-80{ }^{\circ} \mathrm{C}$.

\section{Transformation of agrobacterium competent cells}

Thawing agrobacterium competent cells

Ten ul of $p$ CAMBIA1301-pSTK1-GUS added into $100 \mathrm{ul}$ competent cells, mixed and ice bathed for $30 \mathrm{~min}$. Next, placed in liquid nitrogen for $5 \mathrm{~min}$ and immediately transferred it to a $37{ }^{\circ} \mathrm{C}$ water bath for $5 \mathrm{~min}$. Then $1 \mathrm{ml}$ of YEB added, shook for $5 \mathrm{~h}$ at $28{ }^{\circ} \mathrm{C}$, centrifuged at $220 \mathrm{rpm}$ and supernatant removed. $200-\mu 1$ YEB liquid medium of bacterial suspension added centrifuged at $5000 \mathrm{rpm}$ for $2 \mathrm{~min}$ and supernatant removed. YEB solid medium containing 1\% rifampicin and 5\% kanamycin added and cultured at $28{ }^{\circ} \mathrm{C}$ for $48 \mathrm{~h}$. Finally, a single colony picked and PCR used to identify the positive results.

\section{Genetic transformation of maize germination embryos}

\section{Strain activation}

After preparation, YEB solid medium (1-1 YEB medium $+7 \mathrm{~g}$ agar powder) placed in a high-pressure sterilization chamber of a steam sterilizer. Petri dishes, gun, gun head, a sealing film, an inoculation ring and other tools were also placed in ultraviolet radiation chamber for sterilization and then in autoclave chamber. Bacterial culture taken out of the refrigerator for $30 \mathrm{~min}$ for defrosting. When the medium temperature was moderate, $1 \%$ rifampicin and $5 \%$ kanamycin added in the ultraclean working medium and poured on a flat plate. When the medium solidified, the inoculation ring burned to red with alcohol lamps, and the front of the rod fixed about $7 \mathrm{~cm}$. The outer ring heated for $10 \mathrm{~s}$, and inoculated ring completely cooled. The positive colonies stained with rings, and the culture medium divided into three zones. After the completion of the inoculation, the inoculation ring placed on the alcohol lamp for burning and cooled. After inoculation on the edge of the line, the area crossed again to make two areas. At the end, the third area also inoculated in the same method as it inoculated into other areas. The inoculation completed after burning the inoculation 
ring. After cooling, the metal ring removed and the petri dishes closed with sealing film. Next, placed the petri dish in the incubator in a dark chamber at $28{ }^{\circ} \mathrm{C}$ for $48 \mathrm{~h}$.

\section{Preparation of bacteria}

A single colony of Agrobacterium tumefaciens EHA105 containing $p C A M B I A 1301-p S T K 1$ recombinant expression plasmid transferred on the plate with a sterilized gun tip. Seeded in YEB liquid medium containing 1\% rifampicin $(7.5 \mu \mathrm{l})$ and $5 \%$ kanamycin $(1.5 \mu \mathrm{l}$ ) in a centrifuge tube (size: $2.0 \mathrm{ml}$ ) of $1.5 \mathrm{ml}$, shacked overnight on a $200 \mathrm{rpm}$ speed in a constant temperature shaker at $28{ }^{\circ} \mathrm{C}$ and found positive results as shown in Tables 3 and 4. Bacterial solution transferred into the $50 \mathrm{ml}$ centrifuge tube, $25 \mathrm{ml}$ of YEB liquid medium, 1\% rifampicin $125 \mu \mathrm{l}$ and 5\% kanamycin, $25 \mu \mathrm{l}$ of mixture added and culture shacked well at a constant temperature. The determined OD value was in the range of 0.4-1.2. The material saved at $4{ }^{\circ} \mathrm{C}$ for further use.

Table 3. Primers for GUS

\begin{tabular}{c|c}
\hline Name of primer & Primer sequence \\
\hline Upstream primers: GUS-F & 5-GCAACTGGACAAGGCACT-3` \\
Downstream primers: GUS-P & 5-GAGCGTCGCAGAACATTACA-3` \\
\hline
\end{tabular}

Table 4. Reaction components of bacterial culture medium for PCR

\begin{tabular}{c|c}
\hline System composition & Consumption \\
\hline PCR Master Mix & $5.0 \mathrm{uL}$ \\
GUS-F & $0.5 \mathrm{uL}$ \\
GUS-P & $0.5 \mathrm{uL}$ \\
bacterial fluid & $4.0 \mathrm{uL}$ \\
Total & $10.0 \mathrm{uL}$ \\
\hline
\end{tabular}

\section{Seed sterilization}

Healthy seeds selected with no damage, soaked into $70 \%$ ethanol for sterilization for $30 \mathrm{~s}$; seeds transferred to $5 \%$ sodium hypochlorite for disinfection for $45 \mathrm{~min}$ and rinsed the seeds 5 to 7 times with sterile water. Finally, seeds packed into a sterilized jar (200 tablets), sterilized water added and shaken with the help of a shaker at $90 \mathrm{rpm}$ and soaked overnight. The next day, tubes centrifuged at $4000 \mathrm{rpm}$ for $10 \mathrm{~min}$, supernatant removed and precipitate transferred to the sterile jar. Fresh $1 \%$ rifampicin $125 \mu \mathrm{l}, 5 \%$ kanamycin $20 \mathrm{ml}$, YEB liquid medium $25 \mu \mathrm{l}, 15 \% 5 \mu \mathrm{l}$ of acetosyringone and agar added as transformation and growth medium. Tip of the sterilized blade used to scrape the embryo growth point and placed in the jar. Labeled flasks placed in a thermostatic shaker and incubated at $28^{\circ} \mathrm{C}$ and $90 \mathrm{rpm}$ for $12 \mathrm{~h}$. After those $12 \mathrm{~h}$, the seeds transferred into the nutrient rich soil containing vermiculite and perlite and cultured for $\mathrm{T}^{\circ}$ plant stage. Then set different gradients of $\mathrm{OD}$ value to $0.4,0.6,0.8$, 1.0 and 1.2 and acetyl acetone (AS) with concentration gradient of $50 \mathrm{mmol} / \mathrm{l}$, $100 \mathrm{mmol} / \mathrm{l}, 150 \mathrm{mmol} / \mathrm{l}, 200 \mathrm{mmol} / \mathrm{l}$ and the conversion rate of maize plants was calculated. 


\section{DNA extraction and identification of plant genetic transformation}

When the plant reached the three-leaf stage, $1-2 \mathrm{~cm}$ of blade was cut and put into the centrifuge tube containing $200 \mu \mathrm{l}$ of $\mathrm{NaOH} 0.25 \mathrm{~mol} / \mathrm{l}$ and the tube was centrifuged for $30 \mathrm{~s}$ at $100{ }^{\circ} \mathrm{C}$ constant temperature. $200 \mathrm{ul}$ of $0.25 \mathrm{~mol} / \mathrm{l} \mathrm{HCl}$ and $100 \mathrm{ul}$ of $0.5 \mathrm{~mol} / \mathrm{l}$ of Tris- $\mathrm{HCl}(\mathrm{pH} 8.0, \mathrm{NP}-400.25 \%)$ added to the centrifuge tube. The tube again incubated in boiling water for $2 \mathrm{~min}$. About $2 \mathrm{~mm}^{2}$ of the leaves was picked up after few steps treatment of acid and alkali and this sample used as a template for PCR amplification. The PCR amplification reaction conditions shown in Table 5 and the reaction system components shown in Table 6.

Table 5. PCR amplification reaction conditions

\begin{tabular}{c|c}
\hline Temperature & Duration \\
\hline $94{ }^{\circ} \mathrm{C}$ (Pre-denaturation) & $2 \mathrm{~min}$ \\
$94{ }^{\circ} \mathrm{C}$ (Denaturation) & $90 \mathrm{~s} \mathrm{35} \mathrm{cycles}$ \\
$57^{\circ} \mathrm{C}$ (Annealing) & $1 \mathrm{~min}$ \\
$72^{\circ} \mathrm{C}$ & $2 \mathrm{~min}$ \\
$72^{\circ} \mathrm{C}$ & $5 \mathrm{~min}$ \\
$4^{\circ} \mathrm{C}$ & Saved permanently \\
\hline
\end{tabular}

Table 6. PCR reaction system components

\begin{tabular}{c|c}
\hline System components & Consumption \\
\hline GUS-F & $2.5 \mu \mathrm{L}$ \\
GUS-R & $2.5 \mu \mathrm{L}$ \\
PCR Master Mix & $7.3 \mu \mathrm{L}$ \\
Blade & $\leq 2 \mathrm{~mm}^{2}$ \\
Double distilled $\mathrm{H}_{2} 0$ & $37.7 \mu \mathrm{L}$ \\
Total & $50.0 \mu \mathrm{L}$ \\
\hline
\end{tabular}

Gel electrophoresis machine used to separate different sized DNA fragments. For the preparation of $10 *$ TBE buffer, $108 \mathrm{~g}$ Tris, $7.44 \mathrm{~g} \mathrm{Na} \mathrm{N}_{2} \mathrm{EDTA} .2 \mathrm{H}_{2} \mathrm{O}$ and $55 \mathrm{~g}$ of boric acid was taken in a beaker and $800 \mathrm{ml}$ distilled water was added to the beaker stirred to fully dissolved, volume was raised to $1 \mathrm{~L}$ with addition of distilled water and stored at room temperature. $0.5^{*}$ TBE buffer was prepared by mixing $25 \mathrm{ml} 10^{*} \mathrm{TBE}$ and $475 \mathrm{ml}$ distilled water and stored at room temperature. $5 \mathrm{mg} / \mathrm{ml}$ ethidium bromide(EB)aqueous solution was prepared and agarose gel plates were prepared by mixing $0.2 \mathrm{~g}$ agarose and $20 \mathrm{ml} 0.5^{*}$ TBE in a conical flask by flushing liquid in it. After mixing, the flask placed in the microwave for heating for $1 \mathrm{~min}$ to dissolve fully and then cooled to $60{ }^{\circ} \mathrm{C}$ to add EB drop by drop. After shaking the sample, the combs were fixed, the solution was poured into the sealed gel tank (thickness 3-5 mm) and air bubbles between the comb teeth discharged. Combs taken out after cooling and glue solidification, then gel plate placed into a horizontal electrophoresis tank containing $0.5^{*}$ TBE buffer until the plane thickness of submerged glue became $2 \mathrm{~mm}$. Further, ten to fifteen $\mu \mathrm{l}$ marker sample added in marked gel hole and input of 180 voltage, $100 \mathrm{~mA}$ current to the gel electrophoresis tank provided and samples were run in the gel. Power turned off; gel bands removed from the electrophoresis tank and placed in the gel imager to check the imaging results. To perform GUS 
staining of transgenic plants the configured X-Gluc mother liquor and X-Gluc base solution completely mixed to a volume of $300 \mathrm{ml}$. $\mathrm{T}^{\circ}$ genetically modified transgenic plants and wild-type plants immature and mature roots, young leaves, mature leaves, immature anthers and mature anthers placed in fixed solution of $90 \%$ acetone for 15 min. Rinsed with buffer three times, put into the GUS staining solution, vacuumed and placed in the incubator at $37^{\circ} \mathrm{C}$ in the dark overnight. Next day, samples rinsed three times with $70 \%$ alcohol for decolorization, observed under the microscope, pictures taken and differences analyzed.

\section{Results}

\section{The construction of expression vector}

The digestion of recombinant plasmid pMD18-T-pSTK1 and plasmid pCAMBIA1301 done by Hind III and NcoI restriction enzymes. The digested Hind IIIpSTK1-NcoI promoter and Hind III pCAMBIA1301-NcoI connected with CaMV35S promoter instead of $p C A M B I A 1301$ in the vector. The recombinant plasmid expressing pCAMBIA1301-pSTK1 transferred into Escherichia coli competent cells. After successful transformation, plasmids extracted and transferred into the susceptible state of Agrobacterium tumefaciens. The screening of samples performed and selected colonies used for PCR. The results are shown in Figure 1, Lane 3, Lane 4 and Lane 5 in $1000 \mathrm{bp}$ band.

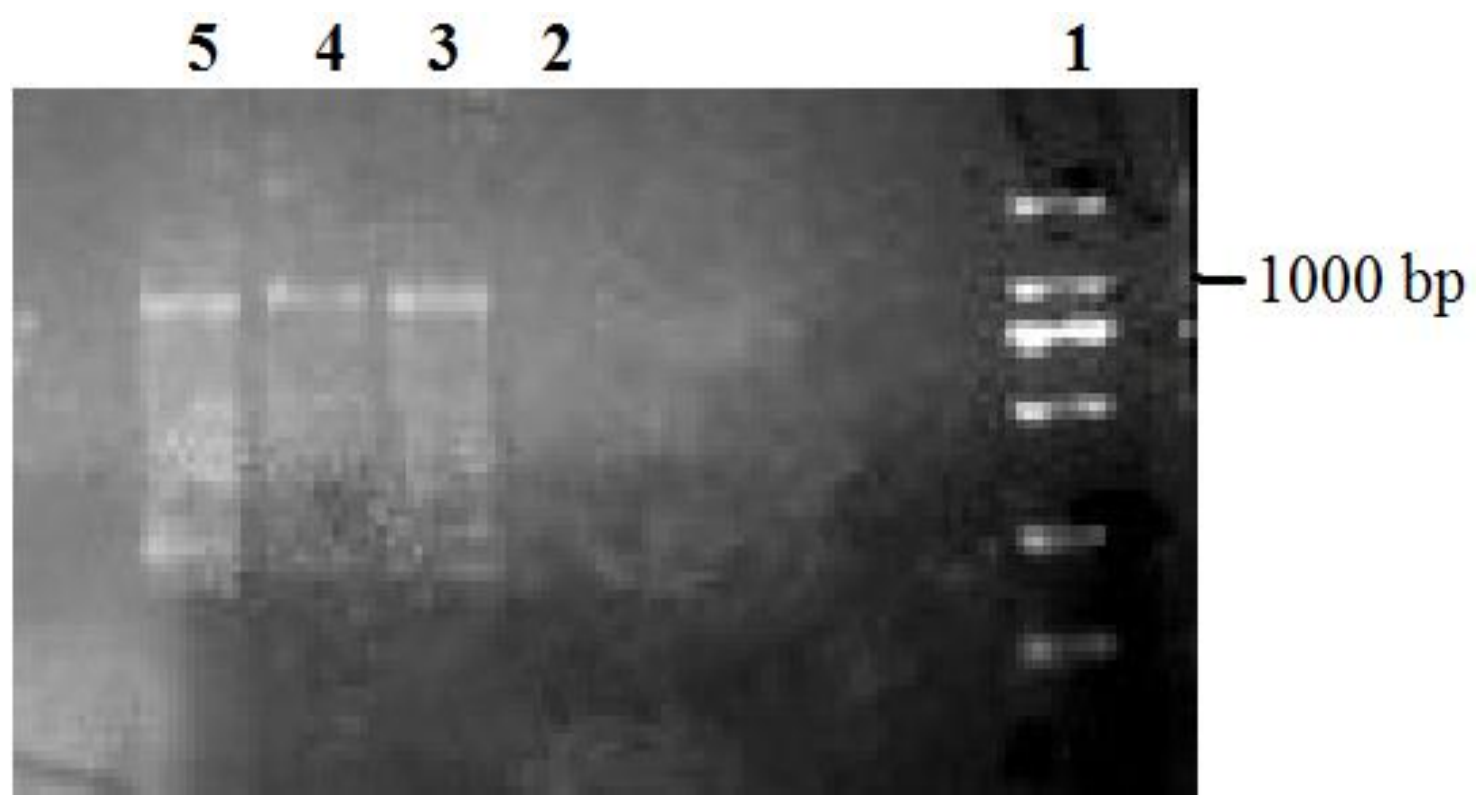

Figure 1. PCR detection of pCAMBIA1301-pSTK1-GUS. (Note: Lane 1 is 2000 marker; Lane 2 is control carrier pCAMBIA1301; Lane 3-5 are the product to be tested)

\section{Identification of active colonies}

Active colonies identified by their activities in PCR amplification and detection through agarose gel electrophoresis. The detection results are shown in Figure 2, Lane 2 and Lane 3 in about $750 \mathrm{bp}$. 


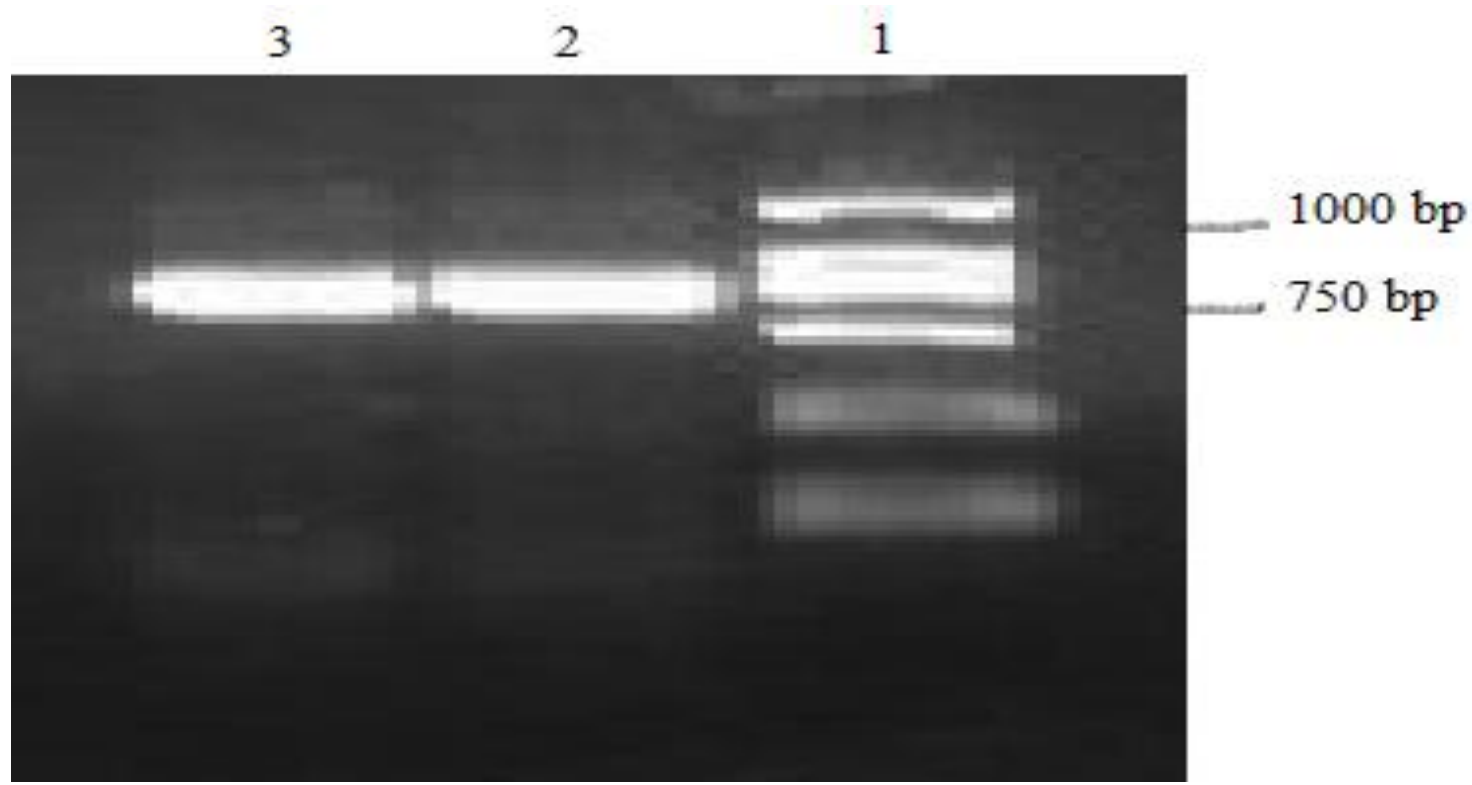

Figure 2. Detection of bacterial liquid PCR. (Note: Lane 1 is 2000 marker; Lane 2, 3 are colonies to be tested)

\section{Optimization of transformation conditions}

Acetosyringone AS can induce the activation of virulent gene in Agrobacterium tumefaciens, and promote the integration of foreign genes. The addition of AS can improve the conversion rate. The maize seeds were treated with different concentrations (OD value were $0.4,0.6,0.8,1$ and 1.2 ) of the bacteria by adding $0.1 \mathrm{mmol} / \mathrm{l}$ acetosyringone (AS) and cultivated at constant temperature of $28{ }^{\circ} \mathrm{C}$. The results showed that different concentrations of bacteria had little effect on seed germination (around 20\%) but affected the seed conversion rate. When the concentration of bacteria was up to $0.8 \mathrm{OD}$ and acetosyringone concentration was $0.1 \mathrm{~mol} / \mathrm{l}$, the transformation rate was maximum.

\section{Regeneration of germinating embryo by genetic transformation}

The inoculated corn seeds cultured in nutrient rich soil containing vermiculite and perlite and 150 grains were sown in each pot $(15 \times 10)$ as shown in Figure 3 .

Total 4000 seeds (200 per plot) incubated into germinating embryos and 807 seeds germinated after Incubation. Only three plants successfully transformed as shown in Figure 4. The pstk- 1 transgenic plants of $\mathrm{T}^{\circ}$ generation obtained by Agrobacteriummediated method. The results showed that when OD value was at 0.8 and concentration of AS was $100 \mathrm{mmol} / \mathrm{l}$, the transformation rate was the best. The germination rate was $20.2 \%$, and the conversion rate was $0.075 \%$.

\section{Transgenic plant testing}

After DNA extraction, PCR amplification and detection from the transgenic plants results showed that there were bands in the samples and detected at around $750 \mathrm{bp}$. The PCR results showed that three seeds out of 4000 seeds successfully transformed (Fig. 5). 


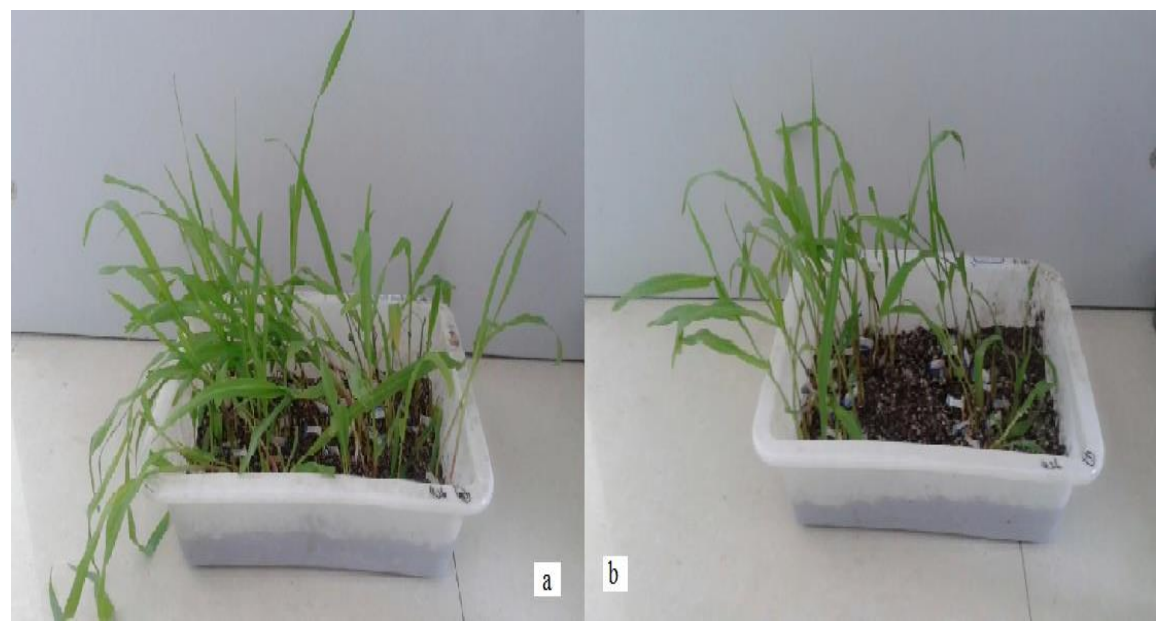

Figure 3. Screening of positive plants
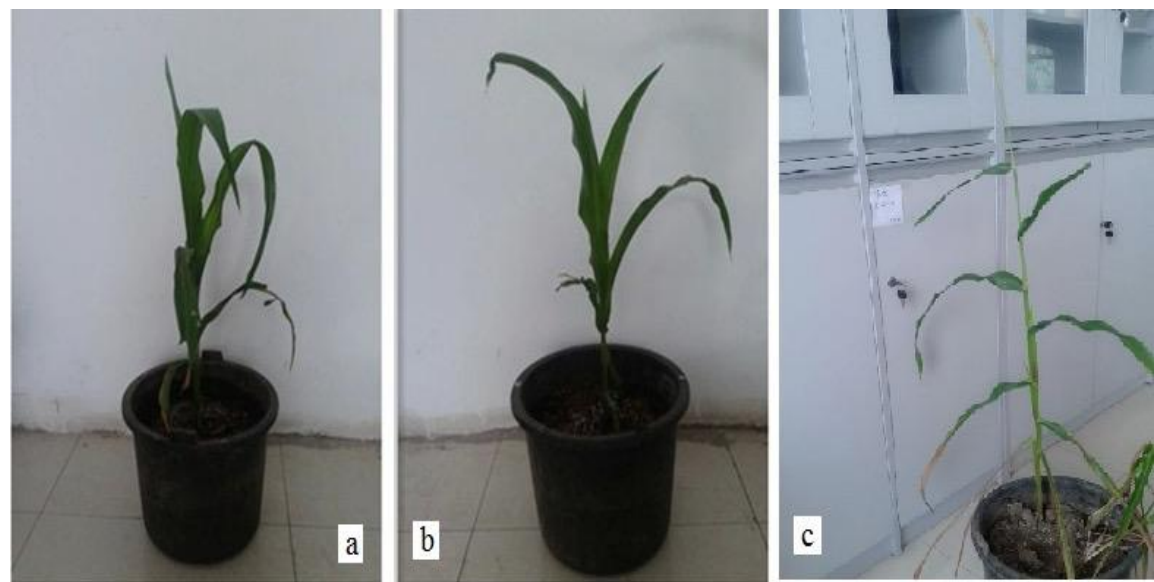

Figure 4. Transgenetic regeneration of positive plants

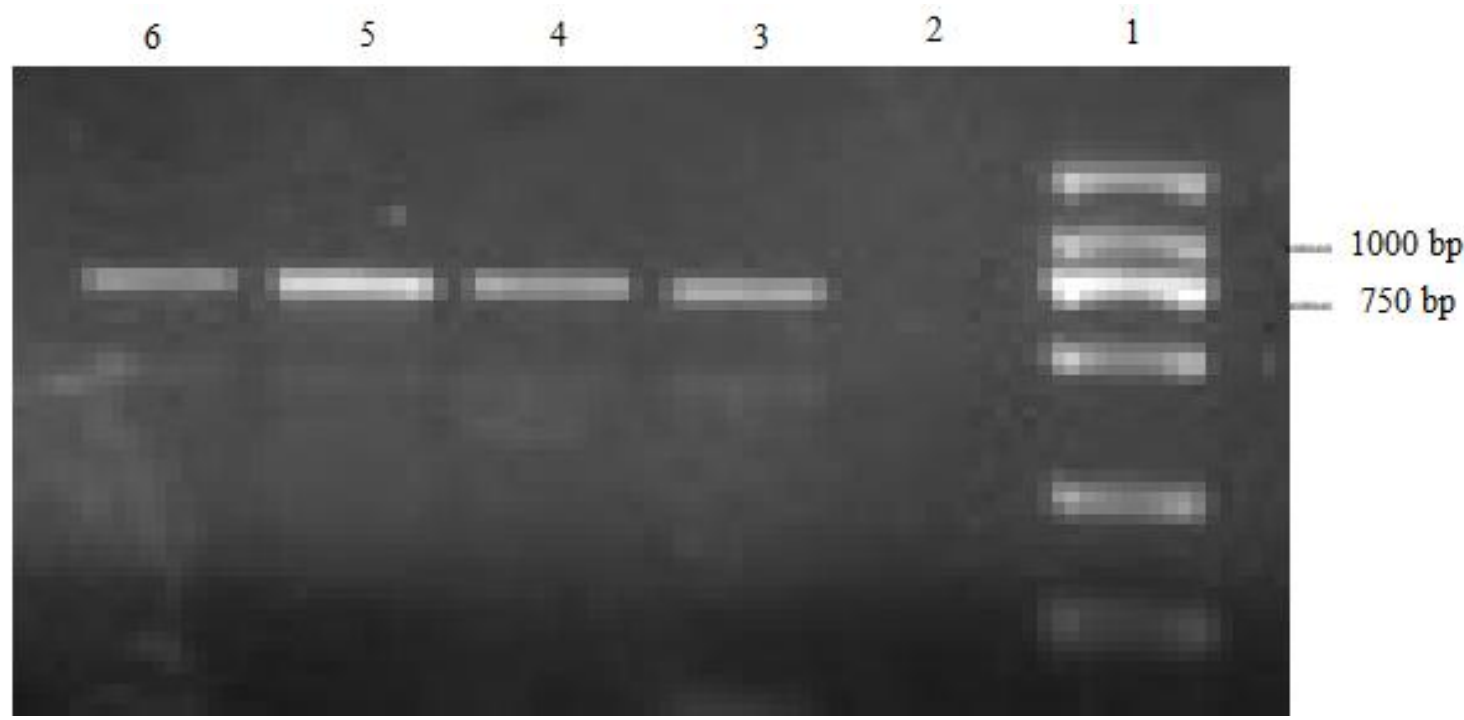

Figure 5. PCR detection of transgenic plants. (Note: Lane 1 is 2000 marker; Lane 2 is nontransgenic plants; Lane 3 is bacterial liquid; Lanes 4-6 are the transgenic plants to be tested) 


\section{GUS staining of regenerated plants}

In GUS staining of non-transgenic plants and PSTK1-GUS plants parts such as immature roots, immature leaves and immature anthers, mature root, mature leaves and mature anthers and mature pollen performed. The results showed that all parts of the non-transgenic plants showed no GUS signal. PSTK1-GUS transgenic plant immature roots, mature roots, immature leaves, mature leaves and immature anthers also showed no GUS signal but the mature anthers and mature pollens showed GUS signal in the form of dark spots as shown in Figure 6.

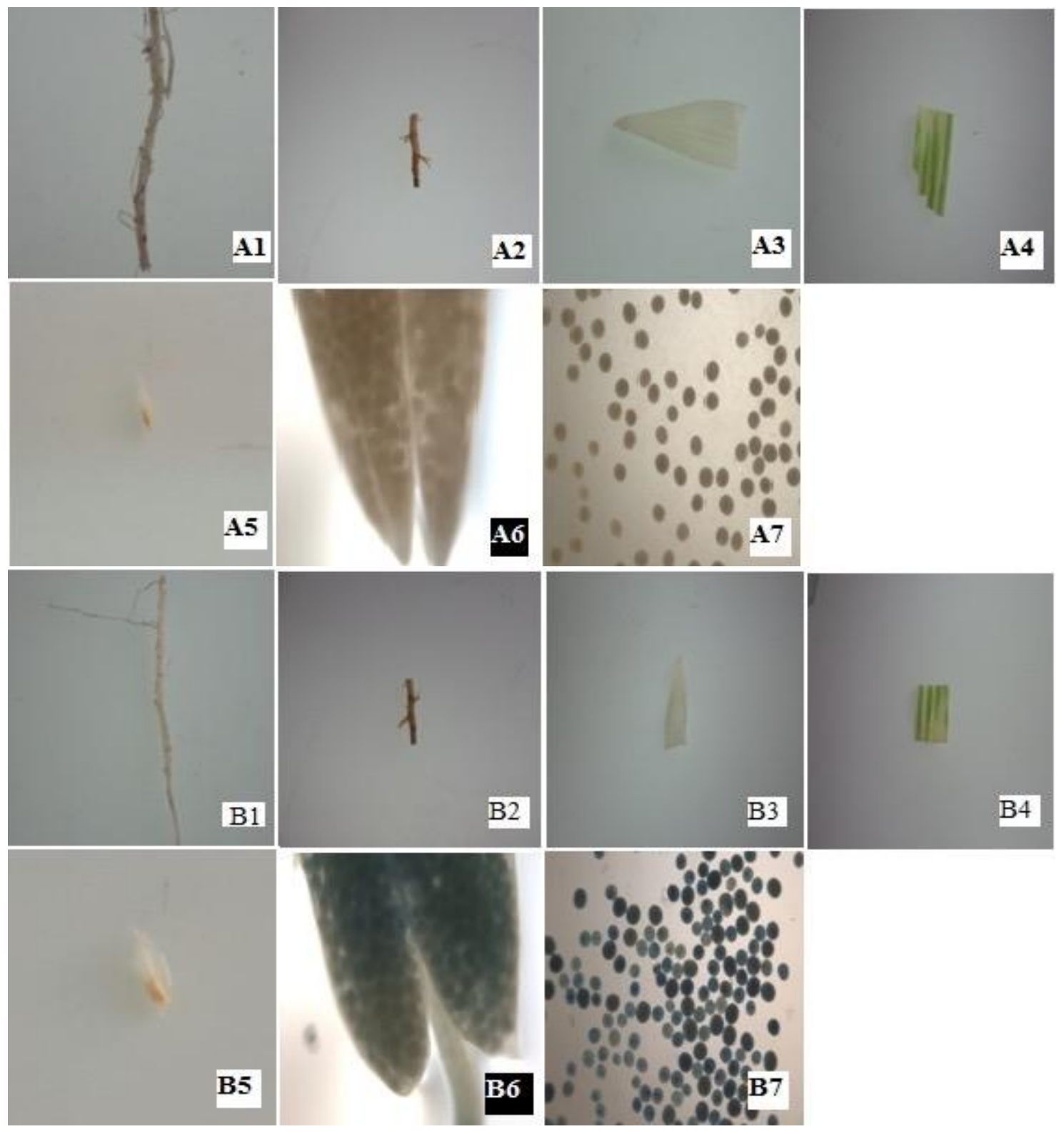

Figure 6. GUS staining for the non-transgenic and PSTK1-GUS plant parts. (Note: A1-A7 are non-transgenic plants; $B 1-B 7$ are PSTK1-GUS plants; $A 1$ and $B 1$ are radicles; $A 2$ and $B 2$ are mature roots; $A 3$ and $B 3$ are immature leaves; $A 4$ and $B 4$ are mature leaves; $A 5$ and $B 5$ are immature anther; $A 6$ and $B 6$ are mature anther; $A 7$ and $B 7$ are mature pollen) 


\section{Discussion}

Genetic transformation is an effective way to increase crop yield and improve quality. With the progress of technology, the method of transgenic maize is continuously improved. In maize, there is a variety of transformation methods, such as electroporation, pollen tube pathway, gene gun, polyethylene glycol, and Agrobacterium-mediated transformation. The receptor of electroporation and polyethylene glycol (PEG) is through protoplast, which is very strict to the preparation and operation of receptor, so it cannot be widely used. The complete pollen tube transformation process is done by natural pollination, without tedious preparation work, breeding required time is short and used directly. Sometimes growing season and flowering stage can affect it. It is also affected by environmental conditions such as temperature, wind, light, rain and more. The bombardment carried out by using the tiny metal particles containing DNA to target the receptor, and DNA injected into the recipient cells by a bilayer lipid membrane. Without host restriction, biolistic method transforms into a variety of plants and improves the plant transformation rate. Moreover, receptor-mediated no-gene type restrictions can be applied to different species and different varieties. It can applied to different organelles with high degree of controllability. However, because the bombardment is random and the conversion rate is relatively low, so multiple copies of the gene are inserted in genome during rearrangement. Prone to a variety of ways, the homologous sequence can be RNARNA, DNA-DNA, or DNA-RNA with each other, causing transcription or posttranscriptional level gene silencing. According to various methods, Agrobacteriummediated transformation has the advantages of relatively stable inheritance, simple operation and high conversion rate. This transformation experiment using Agrobacterium tumefaciens-mediated transformation of maize germinating embryo was time saving, strong repeatability and no need of the corn growing season constraints. It also does not depend on tissue culture can also be done without the process of tissue culture transformation. The receptor of this study, and the concentration conditions of bacteria and AS optimized was also corn-germinating embryo.

After acid and leaf treatment, PCR amplification used to screen the positive plants, which was simple and effective. This method does not need to extract the detected leaf DNA according to traditional procedure, shortened the testing time, only needs leaf area of not more than $2 \mathrm{~mm}$. At the same time, in this method, plant leaf injury is relatively low and the cost is decreased. Therefore, this method has the advantages of less time consumption and high detection efficiency.

GUS detection method is fast, simple and stable. The GUS gene is beta-Dglucuronidase (Gus) gene, X-Gluc can be hydrolyzed into blue material and staining of tissues showed blue spots with GUS activity (visible), so gene expression of GUS detected in specific tissues at exogenous gene site. This is not reported in other gene transfer method. In this study, the PSTK1-GUS gene of $\mathrm{T}^{\circ}$ transgenic plants only had GUS signal in mature anthers and mature pollens, which showed that stk1 promoter only had transcriptional activity in mature pollen. However, for $\mathrm{T}^{\circ}$ transgenic plants, it is not possible to determine whether the inserted fragments are integrated successfully into the genomic DNA or not and further experiments are needed to verify them. 


\section{Conclusion}

The results suggested that the transformation rate to obtain transgenic plants was very low. The GUS staining of non-transgenic and transgenic PSTK1-GUS plants showed no GUS signal. However, mature anthers and pollens showed GUS signal in the form of dark spots, which indicated ZmSTK1 only influences during pollen development and germination. Agrobacterium-mediated gene transformation method is advance and easy for genetic researchers to solve the mysteries behind gene mutation and function at a specific stage.

Acknowledgments. The National Natural Science Foundation of China (grant numbers. 31571672 and 31671707) supported this research.

Ethical approval. This article does not contain any studies with human participants or animals performed by any of the authors.

Conflict of interests. All authors declare that there is no conflict of interests.

\section{REFERENCES}

[1] Bińka, A., Orczyk, W., Nadolska-Orczyk, A. (2012): The Agrobacterium-mediated transformation of common wheat (Triticum aestivum L.) and triticale (x Triticosecale Wittmack): role of the binary vector system and selection cassettes. - Journal of Applied Genetics 53: 1-8.

[2] Boavida, L. C., Shuai, B., Yu, H. J., Pagnussat, G. C., Sundaresan, V., McCormick, S. (2009): A collection of Ds insertional mutants associated with defects in male gametophyte development and function in Arabidopsis thaliana. - Genetics 181: 13691385.

[3] Brittain, C., Kremen, C., Klein, A. M. (2013): Biodiversity buffers pollination from changes in environmental conditions. - Global Change Biology 19: 540-547.

[4] De Carvalho, C. H. S., Zehr, U. B., Gunaratna, N. S., Anderson, J. M., Kononowicz, H., Hodges, T. K. (2004): Agrobacterium-mediated transformation of sorghum: factors that affect transformation efficiency. - Genetic and Molecular Biology 27: 259-269.

[5] Gittins, J. R., Pellny, T. K., Biricolti, S., Hiles, E. R., Passey, A. J., James, D. J. (2003): Transgene expression in the vegetative tissues of apple driven by the vascular-specific rolC and CoYMV promoters. - Transgenic Research 12: 391-402.

[6] Hiei, Y., Komari, T. (2008): Agrobacterium-mediated transformation of rice using immature embryos or calli induced from mature seed. - Nature Protocol 3: 824-834.

[7] Hiei, Y., Ohta, S., Komari, T., Kumashiro, T. (1994): Efficient transformation of rice (Oryza sativa L.) mediated by Agrobacterium and sequence analysis of the boundaries of the T-DNA. - The Plant Journal 6: 271-282.

[8] Huang, J. T., Wang, Q., Park, W., Feng, Y., Kumar, D., Meeley, R. (2017): Competitive ability of maize pollen grains require paralogous serine threonine protein kinases STK1 and STK2. - Genetics: 300358.302017.

[9] Jefferson, R. A., Kavanagh, T. A., Bevan, M. W. (1987): GUS fusions: betaglucuronidase as a sensitive and versatile gene fusion marker in higher plants. - The EMBO Journal 6: 3901.

[10] Lalanne, E., Michaelidis, C., Moore, J. M., Gagliano, W., Johnson, A., Patel, R. (2004): Analysis of transposon insertion mutants highlights the diversity of mechanisms underlying male progamic development in Arabidopsis. - Genetics1 6: 1975-1986. 
[11] Que, Q., Elumalai, S., Li, X., Zhong, H., Nalapalli. S., Schweiner, M. (2014): Maize transformation technology development for commercial event generation. - Frontiers in Plant Science 5: 379.

[12] Shimoda, N., Toyoda-Yamamoto, A., Nagamine, J., Usami, S., Katayama, M., Sakagami, Y. (1990): Control of expression of Agrobacterium vir genes by synergistic actions of phenolic signal molecules and monosaccharides. - Proceeding of Natural Academy of Science 87: 6684-6688.

[13] Shrawat, A. K., Good, A. G. (2011): Agrobacterium tumefaciens-mediated genetic transformation of cereals using immature embryos. - Plant Embryo Culture: Methods and Protocols 710: 355-372.

[14] Sivamani, E., Li, X., Nalapalli, S., Barron, Y., Prairie, A., Bradley, D. (2015): Strategies to improve low copy transgenic events in Agrobacterium-mediated transformation of maize. - Transgenic Research 24: 1017-1027.

[15] Souza, R. A. V., Alves, M. C., Carneiro, N. P., Barros, B. A., Borém, A., Carneiro, A. A. (2017): Agrobacterium-mediated genetic transformation of a tropical elite maize line. Crop Breeding and Applied Biotechnology 17: 133-140.

[16] Vasal, S. K., Riera-Lizarazu, O., Jauhar, P. P. (2006): Genetic enhancement of maize by cytogenetic manipulation, and breeding for yield, stress tolerance, and high protein quality. - Genetic Resources, Chromosomal Engineering and Crop Improvement 2: 159197.

[17] Waines, J., Hegde, S. (2003): Intraspecific gene flow in bread wheat as affected by reproductive biology and pollination ecology of wheat flowers. - Crop Science 43: 451463.

[18] Xi, Y., Ge, Y., Wang, Z. Y. (2009): Genetic transformation of switchgrass. - Biofuels: Methods and Protocols 581: 53-59.

[19] Xing, H. L., Dong, L., Wang, Z. P., Zhang, H. Y., Han, C. Y., Liu, B. (2014): A CRISPR/Cas9 toolkit for multiplex genome editing in plants. - BMC plant Biology 14: 327.

[20] Yadava, P., Abhishek, A., Singh, R., Singh, I., Kaul, T., Pattanayak, A. (2017): Advances in maize transformation technologies and development of transgenic maize. - Front. in Plant Science 7: 1949.

[21] Yang, L., Wang, H., Liu, J., Li, L., Fan, Y., Wang, X. (2008): A simple and effective system for foreign gene expression in plants via root absorption of agrobacterial suspension. - Journal of Biotechnology 134: 320-324. 